\title{
The Impact of Operational Flexibility on Firm Performance: Evidence from Pakistan's Textile Sector
}

\author{
Pervez Akhtar*1 \& Fahad Muqaddas ${ }^{2}$ \\ ${ }^{1,2}$ NUML Business School, Islamabad, Pakistan
}

\begin{abstract}
This paper examines the impact of operational flexibility on firm performance. This research aims to determine the impact of two specific flexibility types on firm performance in the textile industry of Pakistan. Flexibility categories are defined as volume flexibility and material handling flexibility. Both categories of flexibility are significant for a textile sector as the material handling is one of the main issues on the production floor in textile mills, while volume flexibility is the core of competition regarding variety in the product line. The empirical data were collected through a questionnaire addressed to 360 production and operations managers in Pakistani textile companies. Out of which 250 questionnaires that answered all the questions were evaluated and analyzed. The linear regression method was used to identify the impact of volume and material handling flexibility on firm performance. Overall results showed that volume flexibility and material handling flexibility both have a positive impact on firm performance in Pakistan textile sector.
\end{abstract}

\section{Introduction}

Modern business world is universal and aggressive in nature. The quick replacement of products on shelves, short product life cycles, knowledgeable and well-informed customers is the characteristics of modern business environment. These characteristics make manufacturing firms more responsive. For this reason, modern manufacturing systems are expected to be fast, efficient and effective in creating and sustaining the competitive advantage (Duclos et al., 2003). All Over the world, manufacturing industry has experienced a rapid and unexpected change in the last few decades, including changes in competitive behavior, suppliers attitude, customer expectations, production processes, and technology (Wiggins and Ruefli, 2005).

A significant number of authors have viewed the types of intensification and changes in competition (Hum and Sim, 1996; McNamara et al., 2003; Meredith et al., 1994; Spina et al., 1996). These authors are convinced that there are many cases of failure in the business sector because of static business operations. Ford closed its five plants in North America in the past due to shortage of parts. Cell phones manufacturer Ericsson lost its share prices against Nokia in 2000 and ultimately left the handset market because of interruption in chips supply for its new models (Radjou, 2000). Boeing, the maker of the largest airplanes in the world had to bear the loss of $\$ 2.6$ billion in 1997 because two of its suppliers were unable to deliver the critical parts on

*Corresponding author.

Email: pervaizakhtar915@gmail.com time.

The environmental turbulence can be solved considerably through manufacturing flexibility. Organizations are dependent on the environment because they procure inputs and sell their outputs in the same environment. It is the responsibility of top-level managers to build such a relationship with the external business environment that guarantees firms survival in the long run. This is often called a strategy, through which different short-term plans and programs can be formulated (Eppink, 1978). If organizations want to compete successfully, they must upraise flexibility in their operations (Duclos et al., 2003).

This study explores the relationship between operational flexibility and firm performance where operational flexibility (material handling flexibility and volume flexibility) is taken as an independent variable, while firm performance (operational) is a dependent variable. The quantitative method is used to collect the data from 360 textile firms of Pakistan. A seven-point Likert scale questionnaire is used to collect data from production and operation managers. The data is analyzed by using PLS and SPSS statistical packages.

This study is novel in the sense that there are few such studies conducted on manufacturing flexibility on such a significant sample of more than 350 firms in the Textile sector of Pakistan. The combination of volume flexibility and material handling flexibility is not tested yet in the best knowledge of the researcher. The following sections will present the literature on operational 
flexibility and firm performance.

\section{Operational Flexibility Defini- tions in Literature}

There is no single definition of flexibility in existing literature. Flexibility is the strength of any organization to fulfill the increasing expectations of customers without an increase in cost, time, performance losses and organizational disruptions. Flexibility is not a single dimension concept; instead it has multidimensions that can be defined in different ways.

It is a multi-dimensional concept which can be defined in numerous ways. According to Gerwin (1987) flexibility is the ability of an organization handle the uncertain future. Corrêa (1994) defines flexibility as the interaction between external environment and the system of an organization. De Toni and Tonchia (2001) defined flexibility as a concept of adaptation and change. Dixon (1990) associated it with cost, service, and product quality. According to Upton $(1995,1994)$, it is all about providing more and more options to the customers, responding quickly to the customer needs, and performing productively in this regard.

\subsection{Volume Flexibility}

In literature, we cannot find a single agreed definition of volume flexibility. Upton (1994) defines it as the ability of a production system to alter the product volumes. Sethi and Sethi (1990) defined it as the ability of the production facility to operate efficiently and effectively at different levels of output. According to Gerwin (1993) it gives production managers a change to raise or decrease the overall production levels.

Stigler (1939) initiated the study by measuring the volume flexibility with an economics concept average cost curve. According to him, steeper cost curve shows the inflexibility of a firm. Oi (1961) argued that during the price fluctuations period volume flexibility increases the firms profit. Tang and Tomlin (2008) argued that a firm could risk its supply chain by sourcing from an unreliable supplier or it can minimize this risk by taking supplies from a reliable supplier who has volume flexibility. Zailani and Rajagopal (2005) suggested that volume flexibility can be utilized to overcome the problems of replacements on time demanded and claimed by customers. According to Fisher et al. (1997) if firms have better information regarding future demands they can make better decisions of investment to achieve volume flexibility. Anupindi and Jiang (2008) established a strategic relationship between quantity and price under demand vagueness. They concluded, in a competitive business market decision to invest in volume flexibility depends on demand stability.
The point of view presented by different scholars above leads to the formulation of below hypothesis.

\section{$H_{1}$ : Volume flexibility is positively associated with firm} performance.

\subsection{Material Handling Flexibility}

Material handling flexibility is about moving the raw material on a production floor. It is the capability of a system to handle different material types on production floor in such a way that proper processing and positioning can facilitate the overall production process. It covers the transporting of parts, loading and unloading, and finally storing them under the changing conditions of a manufacturing facility. Klotz and Chatterjee (1995) defined material handling flexibility regarding location of machines, the linkage between each pair and group, and time consumed for every potential move between the machines. Sadler and Hines (2002) emphasized on buffer sizes, which can be defined as the ability to adjust and accommodate different shapes, sizes, and adjustment of material moving in an emergency. Flexibility in material handling is very crucial and essential for any firm. The flexible material handling arrangements surge the readiness and utilization of machines and reduces the throughput times.

Flexibility in handling materials can be achieved with automated devices such as pushcarts and fork-lift trucks on the production floor. The layout of the production floor should be supportive of the movement of these automated devices. To have flexible production system devices like robots, automated guided machines, and computer-controlled vehicles would be required to achieve material handling flexibility. These machines can be used to transport different parts to a location where there is a mechanical breakdown or any blockage (Stecke, 1986). Gerwin and Kolodny (1992) conducted research in Sweden and concluded that more space, better layout, better ergonomics, a cleaner environment and use of automated devices could increase material handling flexibility.

The parallel assembly lines facilitate an assembler not to get slower because of a problem. With access to material, the operators become more autonomous of system and staff and can control their activities in an improved way. This can increase material handling flexibility as compared to traditional systems.

Chatterjee et al. (2006) presented a concept of common material handling arrangements that can connect one machine with another. According to them the material handling flexibility is the ratio of paths supported by a common system. de Bie et al. (1998) identified the critical features in material handling devices and assigned weights to these features based on their material handling capabilities to measure the material handling flexibilities. Stecke (1986) estimated that flexible man- 
ufacturing system's performance increases with the increase in material handling flexibility. Stecke (1984) identified subsequent systems to increase flexibility in the manufacturing system. These are roller conveyors, power conveyors, belt conveyors, monorails, mono tractors, and other automatic guided devices. They emphasized on different devices and evaluated them for their influence on different types of flexibilities. Following hypothesis is formulated based on the above literature review.

$\mathrm{H}_{2}$ : Material handling flexibility is positively associated with firm performance.

\subsection{Firm Performance}

According to the existing literature, corporate performance is a multidimensional phenomenon. However, there is no consensus among the researchers that what should be included to measure the firm performance and what should not (Arzu Akyuz and Erman Erkan, 2010). Bourne et al. (2003) did the literature review of past literature on firms operational performance and concluded that it is measured with four main dimensions in the past cost, quality, time and flexibility. Beamon (1999) presented three categories of performance measurement from the supply perspective. They are flexibility, output and source related measures. Gunasekaran et al. (2004), on the other hand, presented performance measures as operative, tactical and strategic.

Beamon (1999) and Gunasekaran et al. (2004) proposed financial measures to judge firm performance which includes sales, profit, and return on investment (ROI). Capon et al. (1990) suggested that performance can be measured through costs, operational efficiency or financial efficiency. According to Hofmann and Locker (2009), firm performance should be measured with both financial and non-financial measures. Martin and Patterson (2009) argued that firms operational performance measures should include lead time and assets utilization. Lai et al. (2002) divided performance into two categories: external performance and internal performance and concluded that measures such as reliability, flexibility, and supply chain responsiveness could be used to measure external performance while cost and assets utilization can be used to measure internal performance.

This research study uses both financial and nonfinancial measure to judge the performance of the Pakistan textile sector. The financial measures are net profit growth (NPG) and sales growth (SG); while, nonfinancial measures are customer satisfaction (CS) and lead time (LT).

\section{Research Methods}

This research study is based on quantitative methods of research. The data are collected through a sevenpoint Likert scale questionnaire from respondents. The unit of analysis for this research is production and operations managers of Pakistans textile firms. The collected data were analyzed by using PLS-smart statistical package and SPSS.

\subsection{Research Model}

\subsection{Sample Selection}

Research population for this study is the textile sector of Pakistan. According to the figures provided by Ministry of textile and Industry and All Pakistan Textile Mills Association (APTMA, 2017) textile sector of Pakistan has 1513 textile processing, printing and finishing mills, (medium and large), The sample was derived out of the total population by using the scientific formula for sampling calculation. As per the statistical research formula, the sample size for this research study is 306 firms approximately. This study is based on large size firms. The size of firms is based on their total capitalization in the textile sector. PXI (Pakistan Stock Exchange Index) data was used to select firms based on their market capitalization. See below Cochran (2007) formula used for sampling.

$$
n_{o}=\frac{Z^{2} p q}{e^{2}}
$$

Where:

- e is the margin of error

- $\mathrm{p}$ is the (estimated) proportion of the population which has the attribute in question,

- $\mathrm{q}$ is $1 \mathrm{p}$.

\section{Results}

Following sections present the results of this research study. The latter part of this section presents the conclusion and recommendations for future research.

\subsection{Factors Loading}

Factors loading results show that there were some factors which did not meet the criteria of .70 on the factor loadings on the reflective construct model. In volume, flexibility constructs all the factors have loading above .70. For volume flexibility, all five factors were 


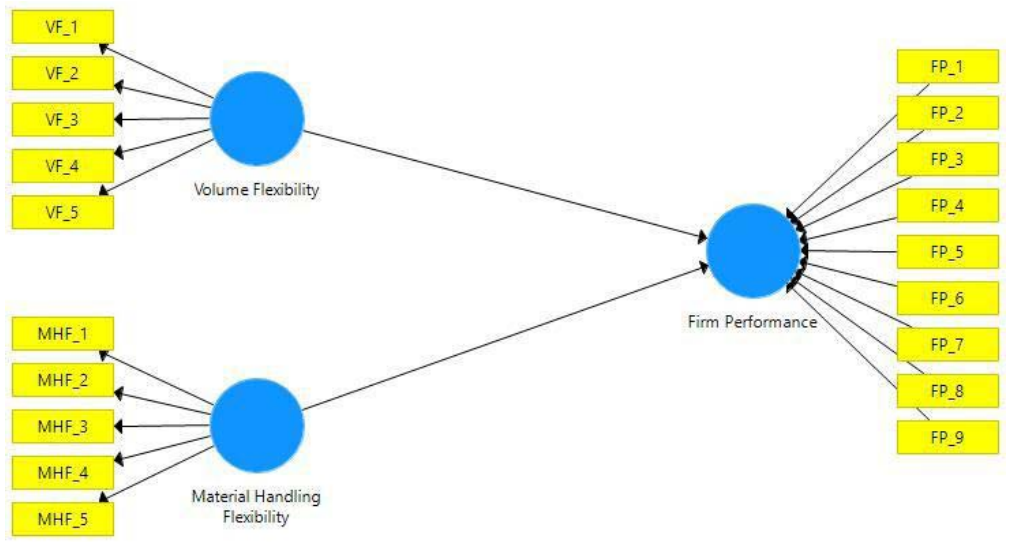

Figure 1: A priori research framework

kept in the final model. While on material handling flexibility all the factors have loading above the statistical criteria that is .70 except factor MHF_4 which was dropped in the final model. On the firm performance factors, only three factors meet the criteria of having factors loading above .70, so all other factors were dropped.

\subsection{Factors Loading \& Final Research Model}

The figures in table 1 show the construct reliability and validity of the scale used in this research. Cronbach's alpha values show that all three variables of this research have a strong loading which are 0.801 for firm performance, 0.856 for material handling flexibility and 0.830 for volume flexibility.

Correlation matrix shows that there is a strong correlation between the independent and dependent variables of this research. Material handling flexibility figures show that it has a correlation of 0.43 approximately which means that there is a strong correlation between material handling flexibility and firm performance. Volume flexibility also has a strong correlation. The correlation between volume flexibility and firm performance is 0.544 . The correlation figures of both independent variables suggest a strong correlation between manufacturing flexibility and firm performance. Both independent variables have a correlation of 0.43 between each other.

To investigate the contribution of independent variables independent variable, a simple regression model was used in which firm performance acted as dependent variable while the volume flexibility and material handling flexibility were taken as independent variables. The linear relationship between the variables was observed as follows.

$$
\mathrm{Y}=\beta 0+\mathrm{X} 1+\mathrm{X} 2+\epsilon
$$

Where,

$\mathrm{Y}=$ firm performance

$\beta 0=$ constant term $\mathrm{X} 1=$ volume flexibility

$\mathrm{X} 2=$ manufacturing flexibility

$\epsilon=$ error term.

Table 3.0 presents the regression analysis results. The relationship between independent and dependent variables is significant $(p=0.00)$ and positive the $R$ Square figure shows that almost $40 \%$ variance is explained by both independent variables of this research in firm performance while the individual variance explained by volume flexibility is 0.389 or $39 \%$ and material handling flexibility has the contribution of 0.36 or $36 \%$ with at statistics of 8.04 .

\section{Discussion}

The overall results are in line with the past research studies. It adheres to the proposition of the resourcebased view theory (RBV) that firm performance is a function of resources mix Fredericks (2005). Many scholars have found similar results if a firm has flexibility in its system through which it can handle variation in demand and supply this will result in better firm performance. The importance of internal resources in creating firm performance and gaining competitive advantage is well known by the executives. So, it is quite notable that how firms differ when they generate, configure and deploy resources to compete within the same industry for higher performance (Hooley et al., 1990; Sirmon et al., 2007).

The material handling flexibility should be in greater control of the organization as it can result in better performance as the results show in this research. Kim and Pekrun (2014) also found the same results that firms with higher level of flexibility enjoy better performance, whereas firms with a lesser level of flexibility face difficulties to achieve their desired goals. 


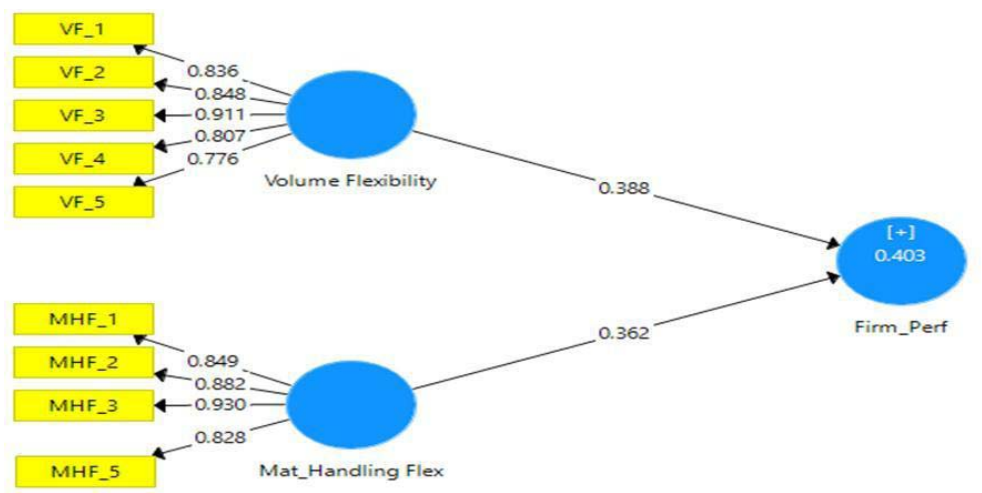

Figure 2: Source: PLS-Smart Output

Table 1: Construct Reliability and Validity

\begin{tabular}{lc}
\hline & Cronbach's Alpha \\
\hline Firm Performance & 0.801 \\
Material Handling Flexibility & 0.856 \\
Volume Flexibility & 0.830 \\
\hline
\end{tabular}

Source: Authors own elaboration

Table 2: Correlation Matrix

\begin{tabular}{lccc}
\hline & Firm Performance & Material Handling Flexibility & Volume Flexibility \\
\hline Firm Performance & 1.00 & & \\
Material Handling Flexibility & 0.439 & 1.000 & 1.000 \\
Volume Flexibility & 0.544 & 0.439 &
\end{tabular}

Source: Authors own elaboration

Table 3: Regression Analysis

\begin{tabular}{ccccc}
\hline & R-Square & Adj. R-Square & t-statistics & p-value \\
\hline Firm Performance & 0.403 & 0.389 & 8.04 & 0.00 \\
\hline
\end{tabular}

Sources: Authors own elaboration.

Kumar et al. (2008) also found a significant relationship between material handling flexibility and firms operational performance. They emphasized on buffer sizes, which means that operational flexibility enables the firm to produce different varieties of a product (i.e. size, design) in case of emergency or expansion.

Volume flexibility also shows a positive relationship with firm performance in this research study. This result is in support of past studies conducted by Cachon and Kök (2007) and Anupindi and Jiang (2008) who established a strategic relationship between quantity and price under demand vagueness. They concluded that in a competitive market decision of investment in volume flexibility could lead to better firm performance.

In the literature on operational flexibility, Parker and Wirth (1999) developed measures of volume flexibility and classify connections between different types of flexibility. Jack and Raturi (2002) used case studies method to segregate the basics of volume flexibility and their impact on firm performance. Vokurka and Lummus (2000) conducted a survey on the literature of volume flexibility and concluded that volume flexibility is positively correlated with firm performance and managers should take timely decision to make their firm's volume flexible.

\section{Conclusion}

Based on the results of this research study and discussion presented in the last part of this research paper it can be concluded that operational flexibility has a positive impact on firm performance. The operational flexibility was presented by volume flexibility and material handling flexibility in this research. The results 
show that volume flexibility has slightly more impact on firm performance than material handling flexibility so, in the textile sector of Pakistan, managers should focus more on volume flexibility in comparison to material handling flexibility however, both are equally important for better performance as the difference between volume flexibility and material handling flexibilitys contribution towards firm performance is not that visible. So, managers should focus on overall manufacturing flexibility so that they can achieve better results.

\subsection{Implications, Limitations, and Future Research Directions}

This research study can be a good guideline for the managers in Pakistans textile sector. They can learn the importance of operational flexibility and its impact on their firm performance. For the future researchers, this study can be a good guideline and source of literature. Moreover, this study is conducted on the textile sector of Pakistan; the future researcher can apply the same model or can enhance this model in other countries or regions especially, the close competitors of Pakistans manufacturing sector, like India, China, and Bangladesh, which have the different business environment.

This study has a limited scope; although many literature sources were reviewed on the impact of operational flexibility and firm performance, it is not possible to cover all relevant sources. So, it is possible that some of the researchers, practitioners and audience disagree with the findings of this study.

\section{References}

Anupindi, R. and Jiang, L. (2008). Capacity investment under postponement strategies, market competition, and demand uncertainty. Management Science, 54(11):1876-1890.

Arzu Akyuz, G. and Erman Erkan, T. (2010). Supply chain performance measurement: a literature review. International Journal of Production Research, 48(17):5137-5155.

Beamon, B. M. (1999). Measuring supply chain performance. International journal of operations $\mathcal{E}$ production management, 19(3):275-292.

Bourne, M., Neely, A., Mills, J., and Platts, K. (2003). Implementing performance measurement systems: a literature review. International Journal of Business Performance Management, 5(1):1-24.

Cachon, G. P. and Kök, A. G. (2007). Implementation of the newsvendor model with clearance pricing: How to (and how not to) estimate a salvage value. Manufacturing $\mathcal{E}$ Service Operations Management, 9(3):276-290.
Capon, N., Farley, J. U., and Hoenig, S. (1990). Determinants of financial performance: a meta-analysis. Management science, 36(10):1143-1159.

Chatterjee, D. D., Segars, A. H., and Watson, R. T. (2006). Realizing the promise of e-business: developing and leveraging electronic partnering options. California management review, 48(4):60-83.

Corrêa, H. L. (1994). Linking flexibility, uncertainty and variability in manufacturing systems.

de Bie, R. A., Verhagen, A. P., Lenssen, A. F., de Vet, H. C., van den Wildberg, F. A., Kootstra, G., and Knipschild, P. G. (1998). Efficacy of $904 \mathrm{~nm}$ laser therapy in the management of musculoskeletal disorders: a systematic review. Physical Therapy Reviews, 3(2):59-72.

De Toni, A. and Tonchia, S. (2001). Performance measurement systems-models, characteristics and measures. International journal of operations $\mathcal{E}$ production management, 21(1/2):46-71.

Dixon, J. R. (1990). The new performance challenge: Measuring operations for world-class competition. Irwin Professional Pub.

Duclos, L. K., Vokurka, R. J., and Lummus, R. R. (2003). A conceptual model of supply chain flexibility. Industrial Management \& Data Systems, 103(6):446-456.

Eppink, D. J. (1978). Planning for strategic flexibility. Long Range Planning, 11(4):9-15.

Fisher, M., Hammond, J., Obermeyer, W., and Raman, A. (1997). Configuring a supply chain to reduce the cost of demand uncertainty. Production and operations management, 6(3):211-225.

Fredericks, E. (2005). Infusing flexibility into business-tobusiness firms: A contingency theory and resource-based view perspective and practical implications. Industrial Marketing Management, 34(6):555-565.

Gerwin, D. (1987). An agenda for research on the flexibility of manufacturing processes. International Journal of Operations $\mathcal{E}$ Production Management, 7(1):38-49.

Gerwin, D. (1993). Manufacturing flexibility: a strategic perspective. Management science, 39(4):395-410.

Gerwin, D. and Kolodny, H. (1992). Management of advanced manufacturing technology: Strategy, organization, and innovation. Wiley-Interscience.

Gunasekaran, A., Patel, C., and McGaughey, R. E. (2004). A framework for supply chain performance measurement. International journal of production economics, 87(3):333-347.

Hofmann, E. and Locker, A. (2009). Value-based performance measurement in supply chains: a case study from the packaging industry. Production Planning and Control, 20(1):6881.

Hooley, G. J., Lynch, J. E., and Shepherd, J. (1990). The marketing concept: putting the theory into practice. European journal of marketing, 24(9):7-24. 
Hum, S.-H. and Sim, H.-H. (1996). Time-based competition: literature review and implications for modelling. International Journal of Operations $\mathcal{E}$ Production Management, 16(1):75-90.

Jack, E. P. and Raturi, A. (2002). Sources of volume flexibility and their impact on performance. Journal of operations management, 20(5):519-548.

Kim, C. and Pekrun, R. (2014). Emotions and motivation in learning and performance. In Handbook of research on educational communications and technology, pages 65-75. Springer.

Klotz, D. E. and Chatterjee, K. (1995). Dual sourcing in repeated procurement competitions. Management science, 41(8):1317-1327.

Kumar, P., Shankar, R., and Yadav, S. S. (2008). Flexibility in global supply chain: modeling the enablers. Journal of Modelling in Management, 3(3):277-297.

Lai, K.-h., Ngai, E., and Cheng, T. (2002). Measures for evaluating supply chain performance in transport logistics. Transportation Research Part E: Logistics and Transportation Review, 38(6):439-456.

Martin, P. R. and Patterson, J. W. (2009). On measuring company performance within a supply chain. International Journal of Production Research, 47(9):2449-2460.

McNamara, G., Vaaler, P. M., and Devers, C. (2003). Same as it ever was: The search for evidence of increasing hypercompetition. Strategic Management Journal, 24(3):261-278.

Meredith, J. R., McCutcheon, D. M., and Hartley, J. (1994). Enhancing competitiveness through the new market value equation. International Journal of Operations $\mathcal{E}$ Production Management, 14(11):7-22.

Oi, W. Y. (1961). The desirability of price instability under perfect competition. Econometrica: journal of the Econometric Society, pages 58-64.

Parker, R. P. and Wirth, A. (1999). Manufacturing flexibility: measures and relationships. European journal of operational research, 118(3):429-449.

Radjou, N. (2000). Deconstruction of the supply chain. Supply chain management review, 4(5):30-38.

Sadler, I. and Hines, P. (2002). Strategic operations planning process for manufacturers with a supply chain focus: concepts and a meat processing application. Supply Chain Management: An International Journal, 7(4):225-241.
Sethi, A. K. and Sethi, S. P. (1990). Flexibility in manufacturing: a survey. International journal of flexible manufacturing systems, 2(4):289-328.

Sirmon, D. G., Hitt, M. A., and Ireland, R. D. (2007). Managing firm resources in dynamic environments to create value: Looking inside the black box. Academy of management review, 32(1):273-292.

Spina, G., Bartezzaghi, E., Bert, A., Cagliano, R., Draaijer, D., and Boer, H. (1996). Strategically flexible production: the multi-focused manufacturing paradigm. International Journal of Operations $\mathcal{E}$ Production Management, 16(11):20-41.

Stecke, K. E. (1984). Variations in flexible manufacturing systems according to the relevant types of automated materials handling.

Stecke, K. E. (1986). Proceedings of the Second ORSA/TIMS Conference on Flexible Manufacturing Systems-Operations Research Models and Applications: Held at the University of Michigan, Ann Arbor, MI, USA, August 12-15, 1986, volume 2. Elsevier Publishing Company.

Stigler, G. (1939). Production and distribution in the short run. Journal of Political Economy, 47(3):305-327.

Tang, C. and Tomlin, B. (2008). The power of flexibility for mitigating supply chain risks. International journal of production economics, 116(1):12-27.

Upton, D. (1995). What really makes factories flexible? Harvard business review, 73(4):74-84.

Upton, D. M. (1994). The management of manufacturing flexibility. California management review, 36(2):72-89.

Vokurka, R. J. and Lummus, R. R. (2000). The role of just-intime in supply chain management. The International Journal of Logistics Management, 11(1):89-98.

Wiggins, R. R. and Ruefli, T. W. (2005). Schumpeter's ghost: Is hypercompetition making the best of times shorter? Strategic Management Journal, 26(10):887-911.

Zailani, S. and Rajagopal, P. (2005). Supply chain integration and performance: Us versus east asian companies. Supply Chain Management: An International Journal, 10(5):379-393. 